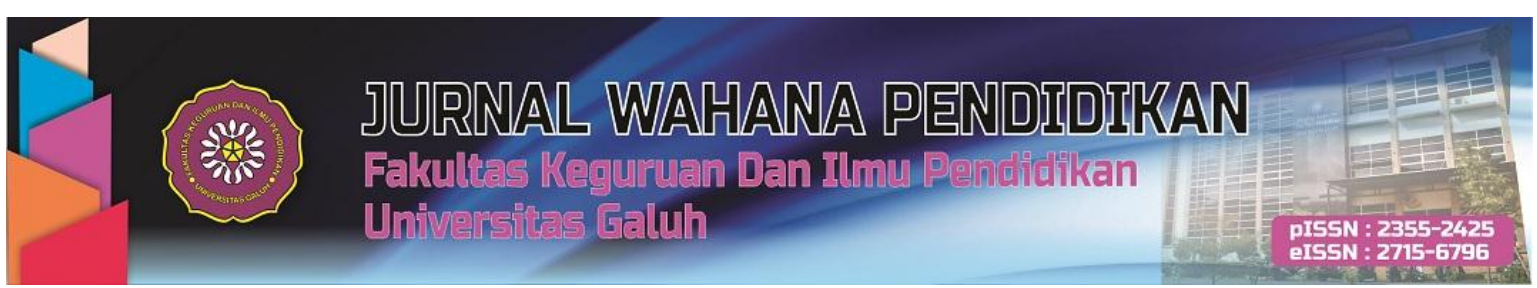

https://jurnal.unigal.ac.id/index.php/jwp

\title{
THE EFL STUDENTS' PERCEPTION OF THEIR FOREIGN LANGUAGE ANXIETY IN SPEAKING CLASS
}

\author{
Dita Anggraeny ${ }^{1}$, Iskhak Said², R. Bunga Febriani ${ }^{3}$ \\ English Education Department \\ Faculty of Teacher Training and Education \\ Galuh University \\ e-mail: dita.surawiangga@gmail.com
}

\begin{abstract}
The purpose of this paper is aimed at investigating the factors that influence foreign language anxiety among the students in a speaking class, and how they perceive about overcoming foreign language anxiety. The present study used a questionnaire to find out the factors that influenced students' foreign language anxiety. An interview was conducted in order to find out the students' perception of their foreign language anxiety. It was found that students felt anxious when they were unable to comprehend communication in class $(62.5 \%)$. Test and speaking in front of class became one of the factors that caused students to experienced anxiety (43\%). On the other hand, fear of receiving bad comments from the teacher and the other students was the third factor that students experienced anxiety $(61.8 \%)$. Through the semistructured interviews, it showed that students reduced the anxiety by practicing the pronunciation, and memorizing the vocabulary. Besides, the teacher played a role in creating and reducing students' foreign language anxiety. The teacher who was able to create an enjoyable learning atmosphere, and focused on student-centered learning, the students argued that it could reduce their foreign language anxiety.
\end{abstract}

Keywords: Speaking, Anxiety, Foreign Language Anxiety

\begin{abstract}
ABSTRAK
Tujuan dari artikel ini bertujuan untuk menyelidiki faktor-faktor yang mempengaruhi kecemasan bahasa asing di antara siswa di kelas berbicara, dan bagaimana mereka memandang tentang mengatasi kecemasan bahasa asing. Penelitian ini menggunakan kuesioner untuk mengetahui faktor-faktor yang mempengaruhi kecemasan bahasa asing siswa. Wawancara dilakukan untuk mengetahui persepsi siswa tentang kecemasan bahasa asing mereka. Ditemukan bahwa siswa merasa cemas ketika mereka tidak dapat memahami komunikasi di kelas (62,5\%). Tes dan berbicara di depan kelas menjadi salah satu faktor yang menyebabkan siswa mengalami kecemasan (43\%). Di sisi lain, ketakutan menerima komentar buruk dari guru dan siswa lain adalah faktor ketiga yang membuat siswa mengalami kecemasan $(61,8 \%)$. Melalui wawancara semi-terstruktur menunjukkan bahwa siswa mengurangi kecemasan dengan mempraktikkan pengucapan, dan menghafal kosa kata. Selain itu, guru berperan dalam menciptakan dan mengurangi kecemasan bahasa asing siswa. Guru yang mampu menciptakan suasana belajar yang menyenangkan, dan fokus pada pembelajaran yang berpusat pada siswa, para siswa berpendapat bahwa itu dapat mengurangi kecemasan bahasa asing mereka.
\end{abstract}

Kata kunci: Berbicara, Kecemasan, Kecemasan Bahasa Asing

Cara sitasi: Anggraeny, D., Said, I., Febrian, \& R. B. (2020)The Efl Students' Perception Of Their Foreign Language Anxiety In Speaking Class. Jurnal Wahana Pendidikan, 7 (1), 29-38. 


\section{INTRODUCTION}

In English foreign language learning, especially in speaking class, students mostly encounter some learning problems. One of the major problems encountered by the students is anxiety. Anxiety can be defined as a mental and physical state characterized by specific emotional, physical, cognitive and behavioral symptoms (Mahmoodzadeh, 2012). Anxiety becomes an obstacle for students in learning English as a second or foreign language because the students need to process linguistic input and produce their thought at the same time (Catagay, 2015). The situation can cause the students to encounter anxiety. Therefore, anxiety becomes an important one among all speaking problems. It is in line with Kasar \& Didem's study (2015), that anxiety is one of the affective factors playing a major role in language learning.

Language anxiety is a negative emotional state, which has a negative impact on how to learn or acquire the target language. It can be a negative emotional state because learners who encounter anxiety might at the same time experience feelings such as apprehension, worry, and dread (Wu, 2015). Besides, they find it difficult to concentrate and forget the things they know. The anxiety that is related to learning a foreign language is referred to as Foreign Language Anxiety (FLA). Students' language anxiety is a real problem that the majority of students face in learning English as a foreign language (Herwanto, 2013). Melouah (2013) stated that language anxiety is the most outstanding factor among the several factors in learning general and specific speaking which influence students' speaking skills they are required to master.

Some previous studies related to language anxiety have revealed the fact that anxiety can impede students in speaking (Sadiq, 2017). One of the studies by Lababidi (2016) explored and investigated the perceptions and experiences of foreign language anxiety (FLA). It is found that the manifestation of language anxiety could be organized under two main categories: psychophysiological and behavioral indicators. Feelings of anxiety were described as being manifested in physical symptoms such as tremors, rapid heart palpitations, sweating and blushing.

EFL learners who encounter foreign language speaking anxiety may lead them to the failure to speak English fluently. Language speaking anxiety forms an essential element that could determine learners' oral production (Akkakoson, 2016). Therefore, this anxiety should be noticed in order to reduce their foreign language speaking anxiety in speaking class that affect to their speaking skill. In a few years, foreign language speaking anxiety becomes a phenomenon that is very interesting to study. It is proven by many studies related to anxiety. In the present study, the researcher focuses on what factors of foreign language anxiety, and how students perceive their anxiety in speaking class.

\section{Speaking skill}

Speaking is one of the abilities that should be mastered by the students as language learners. It means that students may express their desire in a particular situation through communication. According to Harmer (2007), speaking will help the students inform and share what they think. It conveys what they have in their brain. Hence, students have to master speaking skills since it always is used in every activity to communicate with each other.

Nowadays, speaking English is very common in the globalization era. Being able to speak well and fluently in English becomes a basic need for every person in today's era of globalization (Medjahdi, 2015). In consideration of almost every single activity, some activities need English as a tool to speak (Farid, M, 2019). To sum it up, that speaking is one of the language abilities that involve speaker and listener, which is to exchange some information to connect with each other. 


\section{The importance of speaking skill}

A language is a tool for communication. People communicate with others, to express their ideas, and to know others' ideas as well. Sugiarto (2015) said that 'Language is supposed to be an important instrument for the continuing life of human beings in the world'. So, it is very important to master the speaking skill. Everyone can connect to each other, because of the communication in words. People can communicate to the world if we are able to master the speaking English skill, which is one of the languages with the most users in the world. Thus, the ability to speak English fluently can facilitate the students in every aspect of daily activities, because people in the world can connect to each other through direct communication.

\section{Speaking English problems}

Speaking is the most challenging skill of language learning, and it is one of the most negatively influential affective variables (Stawiarska, 2014). Among the speaking English problems, anxiety is mentioned to be the most causes of students' speaking problem. Idri (2012) pointed out that anxiety comes as one of the most outstanding factors due to its pervasive effects on foreign language learning, among the affective factors that influence EFL learners. Research has shown the effect of language anxiety on students' achievement and performance in English language learning (Sadiq, 2017). Thus, students who encounter language anxiety may affect the students' achievement and performance. In conclusion, anxiety has a debilitating effect on the language learning process.

\section{Language anxiety}

Anxiety is a feeling of unease, negative thinking about something in mind marked by excessive uneasiness. Gardner and McIntyre (as cited in Melouah, 2013) state that anxiety in relation to the foreign language anxiety is defined as a negative experience when the learners show negative reactions to particular foreign language learning contexts. Thus, the negative effect of language anxiety can inhibit students in acquiring a language.

Language anxiety is viewed as one of the hindrances for language learners from their successful achievement at a high level of proficiency in a foreign language. Öztürk (2014) stated that students in foreign language classrooms generally report that speaking in the target language is the most anxiety-producing experience. Linas \& Garau (as cited in Aghajani, M. \& Amanzadeh, 2017) suggested that anxiety and in this case foreign language anxiety is the result of language problems that learners may have during their course. Hence, it is important to identify foreign language anxiety in order to help students acquire the target language easily.

We conclude that it is important for the teacher to be aware of using a learning method in order to reduce students' language anxiety. The teacher also has to be able to make an enjoyable classroom atmosphere. Thus, it is important for a teacher to conduct a learning classroom, which is student-centered learning. Therefore, it can give the students the opportunity to be active in class. Thus, the present study has two research questions, those are: what are the factors influencing language anxiety among second-year students in a speaking class? And, how do the students perceive about overcoming the problems of anxiety?

\section{METHOD}

A qualitative research method was employed in this research, which aimed at investigating the students' perception of their foreign language anxiety. This method was used due to the nature of the problems studied implies the research directly to obtain relevant data to the purpose of the research. The present study was a survey study. The researchers selected the second year of the English 
Department as the respondent in this present study. In collecting the data, the researchers used to interview and questionnaire. The kind of interview was the semi-structured interview. The other instrument was a questionnaire. It was conducted to know the students' perception of language anxiety, the sources of foreign language anxiety in speaking class. Finally, the data obtained from interviews and questionnaires were analyzed by generalizing and interpreting the data. Furthermore, the researchers drew some conclusions and gave suggestions based on the findings of the study.

\section{FINDINGS AND DISCUSSION}

In order to answer the first research question, the researchers used a questionnaire to find out the factors of students' foreign language anxiety. The questionnaire consisted of 20 statements. The statements were classified into three factors of language anxiety, namely communication apprehension, test anxiety, and fear of negative evaluation. In interpreting the data, the researchers analyzed the answers by the respondents.

\section{a) Communication apprehension}

The first factors that influencing students' language anxiety was communication apprehension. So, the Communication apprehension factors was on the statement number 1 (doubt to speak English), 4 (fear of not understand the communication in class), 7 (speaking without preparation), 9 (fear of forgetting things), 11 (confidence in speaking with native speakers), 13 (do not want to attend speaking class), 14 (feeling confident to speak in speaking class) and 18 (feeling more anxious in speaking class than other classes). The researchers calculated the results of respondents' answer to the statements into the table 1.

Table 1.

Communication apprehension

\begin{tabular}{cccc}
\hline Number of Statement & SA+A & $\mathbf{N}$ & $\mathbf{D}$ \\
\hline 1 & $68.2 \%$ & $13.6 \%$ & $18.2 \%$ \\
4 & $56.8 \%$ & $27.3 \%$ & $15.9 \%$ \\
9 & $84.1 \%$ & $13.6 \%$ & $2.3 \%$ \\
11 & $90.9 \%$ & 0 & $9.1 \%$ \\
13 & $54.5 \%$ & $13.6 \%$ & $31.8 \%$ \\
14 & $25 \%$ & $34.1 \%$ & $40.9 \%$ \\
18 & $45.4 \%$ & $11.4 \%$ & $43.2 \%$ \\
$\bar{X}$ (Mean) & $75 \%$ & $11.4 \%$ & $13.7 \%$ \\
\hline
\end{tabular}

Based on the table 1, it showed that communication apprehension could influence the students to encounter language anxiety in speaking class. It was proven by $62.5 \%$ of the respondents agreed with the statements in the communication apprehension. The agree score was higher than the neutral and disagree scores. Only $15.6 \%$ answered neither agree nor disagree with the statements, and $21.9 \%$ of the respondents answered disagree with the statements.

\section{b) Test anxiety}

The second factor that influencing students' language anxiety was test anxiety. Test anxiety factor was on the statement number 5 (thinking the others are speaking better), 6 (feeling at ease during test speaking), 8 (worrying the consequence of failing in speaking class), 10 (embarrass to answer teacher's question), 12 (feel anxious in speaking class), and 16 (confused after studying for speaking class). The researcher calculated the results of respondents' answers to the statements into the table below. 
Table 2.

Test anxiety

\begin{tabular}{cccc}
\hline Number of Statement & SA+A & N & D \\
\hline 5 & $52.3 \%$ & $29.5 \%$ & $18.2 \%$ \\
6 & $20.5 \%$ & $25 \%$ & $54.5 \%$ \\
8 & $43.2 \%$ & $38.6 \%$ & $18.1 \%$ \\
10 & $61.4 \%$ & $25 \%$ & $13.6 \%$ \\
12 & $61.4 \%$ & $13.6 \%$ & $25 \%$ \\
16 & $22.8 \%$ & $40.9 \%$ & $36.3 \%$ \\
$\bar{X}$ (Mean) & $\mathbf{4 3 . 6 \%}$ & $\mathbf{2 8 . 8 \%}$ & $\mathbf{2 7 . 6 \%}$ \\
\hline
\end{tabular}

Based on the table 2, it showed that a test in speaking class could influence students to encounter language anxiety. It was proven by $43.6 \%$ of the respondents agreed with the statements. The agree score was higher than the neutral and disagree scores, those were $28.8 \%$ for neutral score and $27.6 \%$ for disagree score.

\section{c) Fear of negative evaluation}

The third factor that influencing students' language anxiety was fear of negative evaluation. The fear of negative evaluation factor were on the statement number 2 (afraid of making mistakes), 3 (tremble when being called), 15 (afraid of getting correction), 17 (feel self-conscious of speaking in front of others), 19 (afraid of being laughed), and 20 (afraid of unexpected questions). The researcher calculated the results of respondents' answer to the statements into the table below.

Table 3.

Fear of negative evaluation

\begin{tabular}{cccc}
\hline Number of Statement & SA+A & N & D \\
\hline 2 & $54.6 \%$ & $6.8 \%$ & $38.7 \%$ \\
3 & $68.2 \%$ & $15.9 \%$ & $15.9 \%$ \\
15 & $43.2 \%$ & $25 \%$ & $31.8 \%$ \\
17 & $75 \%$ & $18.2 \%$ & $6.8 \%$ \\
19 & $47.8 \%$ & $18.2 \%$ & $34 \%$ \\
20 & $81.8 \%$ & $4.5 \%$ & $13.6 \%$ \\
$\bar{X}$ (Mean) & $\mathbf{6 1 . 8 \%}$ & $\mathbf{1 4 . 8 \%}$ & $\mathbf{2 3 . 5 \%}$
\end{tabular}

Based on the table 3, it showed that fear of negative evaluation could influence students to encounter language anxiety. It was proven by $61.8 \%$ of students agreed with the statements. The agree score was higher than the neutral and disagree score, which the scores were $14.8 \%$ for neutral, and $23.5 \%$ for disagree.

In order to answer the second research question, the researchers conducted interview in order to investigate the students' perception of their foreign language anxiety. The researchers also associated the result of the interview with the relevant theory about language anxiety. In the interview, the researchers gave eight questions followed by spontaneous question and conducted to eight students. The result of the interview were as follow.

\section{a) Learning difficulties}

The students faced some difficulties in learning English as a foreign language. The difficulties can lead them to feel anxious, hesitant, and self-conscious when they speak English in speaking class. The researchers had asked the interviewees about the difficulties in speaking English as a foreign language. The result showed that most of students encounter some problems related to learn English. The students explained some problems in learning English such as vocabulary and 
grammar. They also found it was hard to pronounce some English vocabulary since the letter words and the way to pronounce it was different.

Besides, they said that learning English as a foreign language can be a barrier to learn English. They felt difficult to practice speaking English in daily conversation because it is hard to find a partner to speak English. Thus, the difficulties in speaking that causing student's encounter language anxiety is the lack of English use in the daily conversation. The students only used English only in the classroom.

Furthermore, the students seldom use English in daily conversation, since the first language in Indonesia is Bahasa Indonesia. Based on the data above, accustoming students to speak English more, can reduce their difficulties in learning English. Hence, practice makes perfect.

\section{b) Anxiety caused by classroom situation}

In addition to the difficulties in learning English such as grammar and vocabulary, situations in the classroom can also create anxiety in speaking class. The students felt anxious if the other students were able to speak English better than they were. They also felt anxious if the lesson material was difficult.

The data above showed that the classroom situation could lead students to feel anxious in speaking class. The students started to panic when the lecturer asks questions, which the students did not prepare in advance. Thus, it was important for students to be confident in order to reduce the feeling of anxious and nervous.

\section{c) Fear of making mistakes}

The other factors that could create students' language anxiety was fear of making mistakes. Most of students were fear of making mistakes because they were afraid that the other students would laugh at them. Thus, it delivered students to be afraid of making mistakes, and also hesitate to speak in front of class.

Based on the result of the interview, the students were afraid of being laughed by their friends because they were confused about the pronunciation. Besides, the students also did not get used to speak in public. Thus, it could make the students fear of making mistakes in speaking class.

\section{d) Teacher's role}

The other factors that could cause the students' language anxiety was the teacher itself. The students felt anxious when the teacher did not appreciate them. When the students have tried to speak up, instead of correcting the students answer, the teacher were tried to get other answer from other students. Thus, it made the students were confused, trembling, and hesitate to speak again.

Besides, when the lecturer asked the students some unexpected questions, the student would feel anxious to answer the question without preparation. The thrilling lesson also could make students feel anxious. The lecturer who could not make the learning process fun, but stressful could also create the students' language anxiety. It was proven by the student's statement, which shown by the following data.

However, the lecturer also could make the students feel enjoy in the speaking class which was so stressful than the other classes. The enjoyable situation in class could make students would not feel anxious in speaking class. Based on the data of the interview, the role of teacher could lead students to have a language anxiety, or even reduce the students' language anxiety. The way teachers delivered the materials could affect students' language anxiety. Thus, it is important for the teacher to use an appropriate teaching method in order to reduce the students' language anxiety.

\section{e) Overcoming the language anxiety}


In order to overcome the language anxiety, the students had their own perspective about how to reduce their language anxiety. Some of students had a principle to face it even though they did not know whether the answer or what they are talking about was correct or incorrect. The key was they had to face it, not avoid it. Therefore, it could train them to get used to speak English. After getting used to speak English, it would reduce the language anxiety itself.

Besides, the other ways to overcome the students' language anxiety were practice the pronunciation, and memorized what they wanted to say before performing in front of class. The students thought by practicing, they would not feel nervous and tense when they were speaking in front of class. It showed in the result of the interview below.

Based on the data above, students had their own ways to reduce their language anxiety. The ways to reduce their language anxiety based on the students' perspective were by memorizing what they wanted to say, and practicing the pronunciation. Thus, by memorizing and practicing, they believed it would reduce their language anxiety in speaking class.

\section{Discussion}

The researchers used a questionnaire in order to find out the factors that caused students' language anxiety in speaking class. There were three factors that cause students' language anxiety in speaking class, those were communication apprehension anxiety, test anxiety, and fear of making mistakes. Each factor that caused students encountered language anxiety has different symptoms and characteristics. Therefore, the researcher investigated the factors that caused students' language anxiety by adding statements related to the symptoms and characteristic each factors in the questionnaire.

\section{a) Communication apprehension}

The factors that provoked students encountered language anxiety is the inability to comprehend what was being discussed or said in the classroom The data from questionnaire showed that communication apprehension could influence the students to encounter language anxiety. It was proven that $62.5 \%$ of the respondents agreed that communication apprehension became one of the factors that the students encountered language anxiety in speaking class. Thus, the students who suffered to comprehend the communication in speaking class would be difficult to improve their speaking English ability. Based on the data from questionnaire, the students would be frightened when they did not understand what the teacher was saying. Students who experience a high level of communication apprehension withdraw from and seek to avoid communication when possible.

\section{b) Test anxiety}

Based on the result of the study, most of students felt anxious when they have a speaking test. The data from the questionnaire showed that test in speaking class could influence students encountered language anxiety. $43.6 \%$ of the respondents agreed that facing a speaking test was one of the sources of their language anxiety. However, they were hardly to volunteer answering the teacher's questions in the class. Besides, they also feel intimidated when others speak better than they do. Thus, it could make the students did not feel at ease during test in speaking class.

\section{c) Fear of negative evaluation}

Based on the result of the study, it was found that the students were fear to get the negative evaluation about their performance in speaking class. The data from questionnaire showed that $61.8 \%$ students agreed that fear of negative evaluation became the factor that the students encountered language anxiety. It encouraged students to be careful when they spoke in front of class in order to not causing problems that would be corrected by the teacher later, or even laughed 
at by their friends because they mispronounced some words. In the questionnaire, most of students agreed with the nineteenth statement "I am afraid that the other students will be laugh at me when I speak English". Thus, it tends to make students feel afraid and nervous in speaking class.

\section{d) Students' perception of overcoming their foreign language anxiety}

The findings of the research showed that the students found it was difficult to comprehend speaking ability. They faced some learning difficulties, which became the barriers for students to be able to speak English fluently. Thus, the students would encounter language anxiety that influenced to students' speaking ability. It was found some learning difficulties in speaking that the students faced, those were lack of vocabulary, fear of making grammatical errors, and pronunciation. They stated that they were lack of vocabulary, difficult to order the words in a sentence, and did not know how to pronounce some words. The learning difficulties above could lead them to have language anxiety in speaking class.

The students had several ways in order to overcome their language anxiety. The researchers found that students would feel less anxious when they have memorized what they would talk about before performing in front of the class. Besides, the students also had to practice the pronunciation in order to not making a mistake while they were speaking in front of the class, which was causing them to feel anxious. Otherwise, the teacher also has an important role in creating and reducing the students' language anxiety. Teachers in language classes sometimes ignored the fact that the students will probably feel uncomfortable in class due to the techniques of teaching. However, the researchers also found that the students would not feel anxious if the teacher was able to make the learning activities fun and enjoyable. It is essential for teachers to be friendly and make some fun class activities rather than being strict and uncared with the students. In addition, it is important for the teacher to use the appropriate learning methods, models, and strategies in order to make the students would not feel anxious in English class, especially in speaking class.

\section{CONCLUSION}

Based on the finding and discussion of the research, the researchers could conclude that the factors influencing students' language anxiety in the speaking class were communication apprehension, test anxiety, and fear of negative evaluation. The communication apprehension was the inability students to comprehend what was being discussed or said in the classroom, which provoked students to encounter language anxiety. The present study found that most of the students were not sure to speak English, fear of not understand the communication in class, afraid to speak without preparation, fear of forgetting things. They also felt not confidence when they spoke with native speakers. Thus, the students tent to skip the speaking class since they felt more anxious in speaking class than the other classes.

The research showed that the students were difficult to comprehend speaking ability. They faced some learning difficulties, which became the barriers for students to be able to speak English fluently. The researchers found some learning difficulties in speaking that the students faced, those were lack of vocabulary, fear of making grammatical errors, and pronunciation. The students had to memorize what they were going to talk about before performing in front of the class. The students would feel less anxious when they have memorized what they would talk about before performing in front of the class. Besides, the students also had to practice the pronunciation in order to not making a mistake while they were speaking in front of the class, which was causing them to feel anxious. Otherwise, the teacher also has an important role in creating and reducing the students' language 
anxiety. The students would feel anxious when the teacher made the situation in class tense. The learning method, which the teacher used also could affect the students' language anxiety. The students would not feel anxious if the teacher was able to make the learning activities fun and enjoyable.

For further researchers, it is highly recommended to investigate a learning technique or method to cope with students' foreign language anxiety. The further research related to foreign language anxiety is also suggested can find a more effective foreign language learning in order to cope with the students' foreign language anxiety through better research design, instruments, and analysis.

\section{REFERENCES}

Akkakoson, S. (2016). Speaking Anxiety in English Conversation Classrooms among Thai Students. Malaysian Journal of Learning and Instruction. 13(1), 63-82.

Aghajani, M. \& Amanzadeh, H. (2017). The Effect of Anxiety on Speaking Ability: An Experimental Study on EFL Learners. Journal of Applied Linguistics and Language Research. 4(7), 154164.

Catagay, S. (2015). Examining EFL Students' Foreign Language Speaking Anxiety: The Case at a Turkish State University. Procedia - Social and Behavioral Sciences. 199(3), 648-656.

Farid, M. (2019). The Effectiveness of Using Ted Talks Video in Improving Students Public Speaking Skills in Senior High School. JALL (Journal of Applied Linguistics and Literacy), 3(1), 61-74.

Harmer, J. (2007). The Practice of English Language Teaching. Harlow: Longman

Herwanto, R. (2013). Factors That Cause Language Anxiety in the English Classroom Speaking Performance in SMP Negeri 4 Pakem Yogyakarta. Thesis. Universitas Negeri Yogyakarta, Indonesia.

Idri, N. (2012). Foreign Language Anxiety Among Algerian EFL Students: The Case of first year Students of English at the University of Abderahmane Mira-Béjaia; LMD (Licence/ Master/ Doctorate) System Group. Universal Journal of Education and General Studies. 1(3), 055-064.

Kasar, S. O., \& Didem, T. (2015). Language: The Example Of Gazi Univesity Turkish. International Journal Of Languages' Edcation And Teaching. 3(3), 1062-1073.

Lababidi, R.A. (2016). Language Anxiety : A Case Study of the Perceptions and Experiences of Students of English as a Foreign Language in a Higher Education Institution in the United Arab Emirates. English Language Teaching. 9(9), 185-198.

Mahmoodzadeh, M. (2012). Investigating Foreign Language Speaking Anxiety within the EFL Learner's Interlanguage System: The Case of Iranian Learners. Journal of Language Teaching and Research. 3(3), 466-476 
Medjahdi, W. (2015). Reading comprehension difficulties among EFL learners: The case of thirdyear learners at Nehali Mohamed Secondary School. (Unpublished master thesis). University of Tlemcen.

Melouah, A. (2013). Foreign Language Anxiety in EFL Speaking Classrooms: A Case Study of Firstyear LMD Students of English. Algeria: Saad Dahlab University of Blida. 4(1), 64-76.

Öztürk, G., \& Saydam, D. (2014). Anxiety and Self-efficacy in Foreign Language Writing: The Case in Turkey Yabancı Dilde Yazmada Özyeterlik ve Kaygı: Türkiye ' de Bir Durum Çalışması. Başkent University Journal Of Education. 1(2), 10-21.

Sadiq, J. (2017). Anxiety in English Language Learning: A Case Study of English Language Learners in Saudi Arabia. English Language Teaching. 10(7), 1-7.

Shabani, M. B. (2012). Levels and sources of language anxiety and fear of negative evaluation among Iranian EFL learners. Theory and Practice in Language Studies. 2(11), 2378-2383.

Stawiarska, M. M. (2015). Investigating Foreign Language Speaking Anxiety Among Advanced Learners of English. Issues in Teaching, Learning and Testing Speaking in a Second Language, Second Language Learning and Teaching. Linguistica Silesiana. 35(10), 103-119.

Sugiarto, B.R., Sofwan, A., \& Sutopo, D. (2015). Mood Realization of the Learning Activities in the Grade VII English Textbook Published By the Ministry of Education and Culture. English Education Journal, 5(1).

Wu, A. (2016). An Investigation into the Relationship between Genders and Foreign Language Anxiety. Thesis, Fu Jen Catholic University. 